\title{
The C-U-C training mode of Applied Innovative Talents Based on scientific research platform
}

\author{
Shidan $\mathrm{He}^{1, a}$,Yaqi $\mathrm{Xu}^{1, \mathrm{~b}}$ \\ ${ }^{1}$ Xijing University,Xian,China,710123 \\ a heshidan@xijing.edu.cn
}

\begin{abstract}
Keywords: the C-U-C training mode; technical innovation talents; training mode
Abstract. The C-U-C training mode combined with the development needs of local industry and technology, which is from the application of innovative talents training objectives that construct the curriculum system, practice teaching system and quality control system. The C-U-C training mode is promoting the practice teaching platform and the construction of teaching staff, which has been proved by practice that it is a successful attempt to carry out the training mode of applied technical innovation talents. This paper has the reference value to the Teaching Department of university laboratory and professional construction.
\end{abstract}

\section{Introduction}

The fundamental task of scientific research platform is cultivating high-quality innovative talents, which Based on the background of scientific research platform. The local colleges are put forward for cultivating application-oriented and innovative talents, but the talent can be divided into four class which academic and engineering type, technology type and skill type, that were cultured by the academic education, engineering education, technical education, technical education faculties. We think that the research mainly consists of research universities is to cultivate innovative talents, talents and innovative works mainly to cultivate innovative talents by the teaching research universities, which technology mainly consists of teaching university culture, and creative talents mainly by training in colleges. The cultivation of technical innovation talents is the duty and mission of teaching university, which is also the need to cultivate innovative talents with sustainable development potential.

\section{The clear training orientation}

With the development of society and technology, we analyzed the changes of local and industry demand for electronic information professionals, which is referring to the domestic and foreign higher education experience. We combine the C-U-C model adhere to the people-centered education, and technology applied innovative talents training as the center[1], which is adhering to the "continuous improvement" construction idea.at the same time, we take the system design to the project as the starting point. The characteristics of technology reflect the organic combination of "application type" and "innovative", which is focusing on the training of technical personnel in the training process technology application ability, technology ability and technical innovation ability. The training of applied innovative talents should be with the local economic construction and the development of the industry that needs to build in order to improve the practical ability and innovative ability by C-U-C personnel training mode. Scientific research platform apply innovative talents training mode is based on the theory research of C-U-C technology as the foundation which is to the quality of training as the key to innovation consciousness as the core, adhere to the people-centered education promote the comprehensive and coordinated sustainable development of science and technology talents whose training objective is to cultivate the scene engaged in the production. 


\section{The promote of platform construction}

The C-U-C platform is the key of innovative talents training, which the difficulty is the construction of teachers. We are in order to promote the effective implementation and operation of the project, who continue to strengthen the practice teaching platform and faculty development.

The practice platform construction. The college established the electronic information technology education center, and set up across 5 technical disciplines ${ }^{[2]}$, and builds 4 platform experimental training. The knowledge and technology curriculum as the main line based on the experimental organic curriculum group fusion into several modular experimental courses by applied innovative talents training under the background of scientific research platform in $\mathrm{C}-\mathrm{U}-\mathrm{C}$ system mode, which give full play to the same experimental technique, and similar experimental methods for the cultivation of comprehensive practical ability. The center adheres to the principle of technically advanced, and economically reasonable and suitable for teaching. The basic equipment mainly consider the development and application of comprehensive application ability ,but which also to consider whether the device is in favor of cultivating talents, to stimulate interest in the process of vivid.

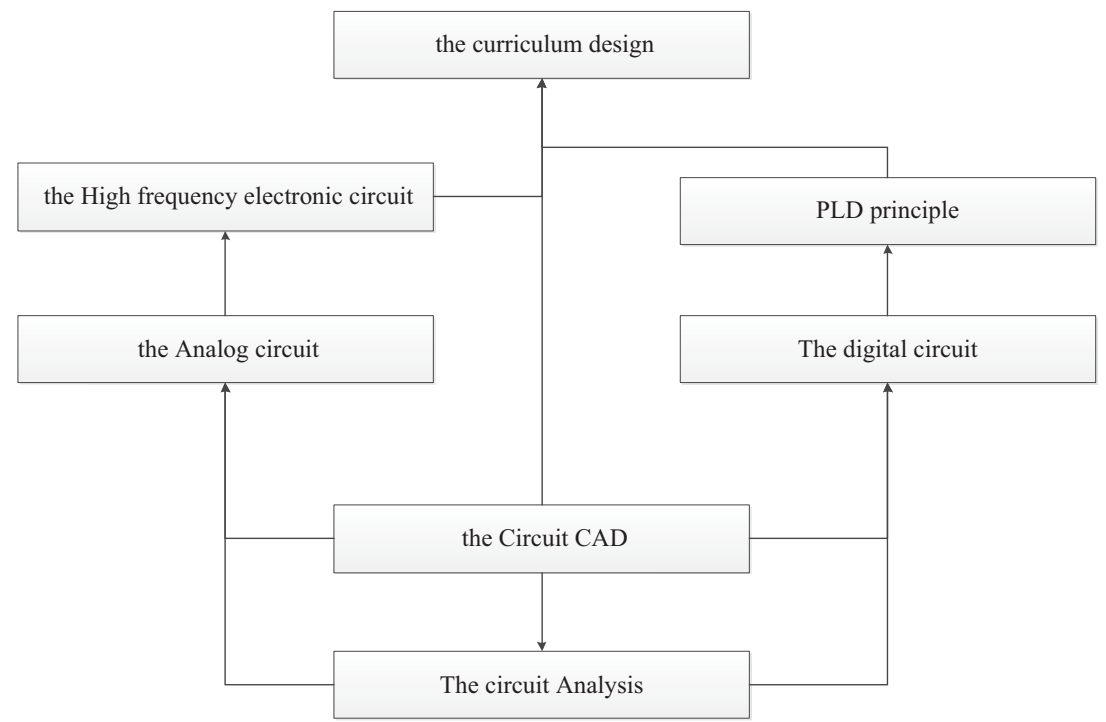

Fig1. The course system structure of electronic technology

The teachers' platform construction. Our school issued 《the views about strengthening the young teachers' professional practice》, 《teachers participate in professional practice and training management approach》, 《the growth of young scientific talent support program implementation measures》, and a series of incentive mechanism, which strengthen the cultivation of teachers' practical innovation ability.

At the same time, we can improve teachers' practical innovation ability as fellow 4 aspects:

(1)We promote the experimental conditions, course construction, teaching team construction organically, and the growth of teachers through the experimental conditions;

(2) We promote the growth of teachers, which is leading to the growth of the teacher curriculum construction, and curriculum construction that to update the teaching contents;

(3) We encourage teachers to the school and enterprise training;

(4) We lay a solid foundation for personnel training by multiple ways to effectively promote the growth of teachers, and want to ensure the quality of personnel training.

\section{The build of talent training system}

The applied innovative talents should possess from innovative talents training objectives, and the construction the electronic information professional technology system, practice teaching system and quality control system[3]. 


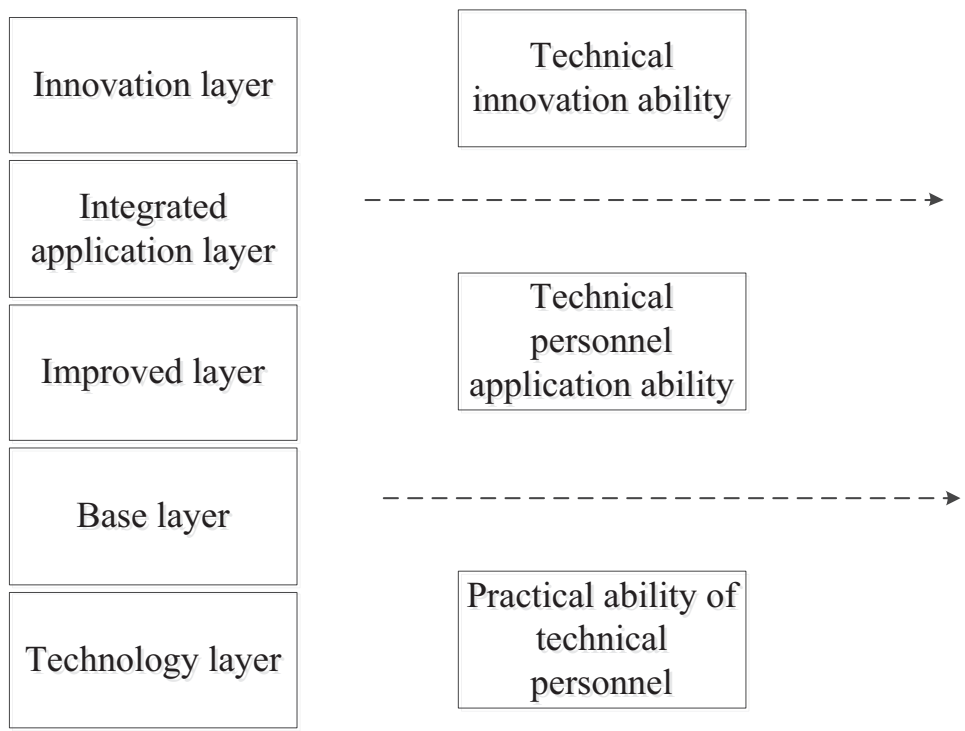

Fig2.the C-U-C application training system

The professional research system. The scientific research platform applied innovative talents training mode based on the teaching in Application-oriented University, so curriculum structure should use the "II" type course system. The C-U-C mode should base on the background of scientific research platform, and to strengthen the proportion of specialized courses and practical courses, which is conducive to the cultivation of skilled personnel. We strengthen the cultivation of talents and technology innovation spirit, who carry out the innovation of credit system.

Table1. The C-U-C application training system content

\begin{tabular}{lll}
\hline layer & Hierarchical practice module & Ability training \\
\hline Practice layer & $\begin{array}{l}\text { Electrical and electronic basic skills training, which is Basic } \\
\text { computer skills training Engineering software foundation } \\
\text { training Modular }\end{array}$ & $\begin{array}{l}\text { Training the basic practical } \\
\text { skills }\end{array}$ \\
& $\begin{array}{l}\text { The Basic application courses Module, the main courses In } \\
\text { process unit module design Integrated curriculum } \\
\text { Improved layer }\end{array}$ & $\begin{array}{l}\text { Enhance the Ability of } \\
\text { analyze and solve problems }\end{array}$ \\
Integrated layer & $\begin{array}{l}\text { Course design, graduation Practice of graduation and } \\
\text { graduation design Modular }\end{array}$ & $\begin{array}{l}\text { Cultivating students' } \\
\text { comprehensive application } \\
\text { Capability } \\
\text { cultivate students Research } \\
\text { Innovation layer }\end{array}$ \\
& $\begin{array}{l}\text { Innovative experiment plan, Electronic games and challenges } \\
\text { Cup, student scientific research project, Extracurricular }\end{array}$ & \\
& science and technology activities, students Participate in \\
teacher research & Practical modules & \\
\hline
\end{tabular}

College should combine with electronic information specialty, construction 4 modules, namely respectively, curriculum science and technology courses in electrical and electronic technology. We are In order to cultivate innovative talents with technical application, students and other factors set up a series of lectures for professional introduction. College set up the "basic skills" electrical and electronic training courses in the first semester, the purpose is through component identification. The basic test instrument is use and simple manufacture of electronic products and other basic skills training, learning interest and enthusiasm to stimulate technological talents. We cultivate talents of technology application ability and innovation ability, which are according to the relevance of the curriculum to integrate the curriculum. The optimal culture curriculum highlights that the basic science and technology talents practice ability, application ability, technical innovation ability, which cultivate talents to promote science and technology talents ${ }^{[4]}$.

The practice teaching system. The C-U-C model is based on the technical application ability, and the training practice teaching idea with the aim of the technological innovation ability. The five levels of practice teaching system which is the combination of internal and external courses. The basic practical skills layer can train the basic practical ability of scientific and technological talents improve the application ability in the layer, and change the technical ability. The basic skills of 
electrical and electronic correspond to the basic practical skills in the course, which correspond to the base layer. Scientific and technological talents required innovative credit content corresponding to the innovation level. The combination of science and technology talents on the basis of science and technology talents reserves, which as the main body, and adopt different teaching methods.

The quality control system. The C-U-C mode establishes a goal of talent training as the core, which is to improve the quality of teaching that is the teaching quality monitoring system. The quality monitoring system should adapt to the mode of talent training, and technical education is result oriented education that is to cultivate the target oriented training and graduation requirements. We need to establish the effective mechanism of continuous improvement that improvement the main circulation if the school graduation requirements, and in order to achieve the continuous improvement of graduation requirements. The outside circulation is mainly on the improvement of training objectives, which is training objectives through the timely evaluation and reach conformity, thus we are improving the graduation requirements, and adjusting the training objectives, that is in order to achieve continuous improvement of training objectives.

\section{Conclusion}

We combined with the development needs of local industry in the development and transformation of local colleges, who through dislocation development to nurture characteristics after 10 years of research and practice. We want to establish a platform for scientific research under the background of Applied Innovative Talents Training Mode which is based on C-U-C mode, and personnel training are effect, steady improvement in the quality of employment. Our school of electronic information professional science is innovation and entrepreneurship training project in the past 4 years, which including 7 provincial and ministerial level scientific and technological personnel. Science and technology talent won more than 267the national and Chongqing municipal third-prize, which is including 12 national science and technology talents. We get radio attached workers, that maintenance electrician, and 621 occupation qualification certificates, the conversion rate have been more than $85 \%$.

\section{Acknowledgments}

Xijing University research,project number: XJYJ1612

\section{References}

[1]Wan Lin, Zhang Ping. Cultivating innovative talents is the fundamental task of colleges and universities [J]. Education, 2015 (1): 2526.

[2]See Shen Yaqiang, Zhang. The relationship between education and occupation[J]. Education, 2012:12-62

[3]Xia Jianguo. The difference and relationship between engineering education and technical education from three international education agreements $[\mathrm{J}]$. higher education research, 2012, (.2) 116-121.

[4]Xu Han, Yang Keju. the connotation of technical undergraduate education: Based on technology education and science education [J]. Education Forum, 2013, (10) 4-11. 